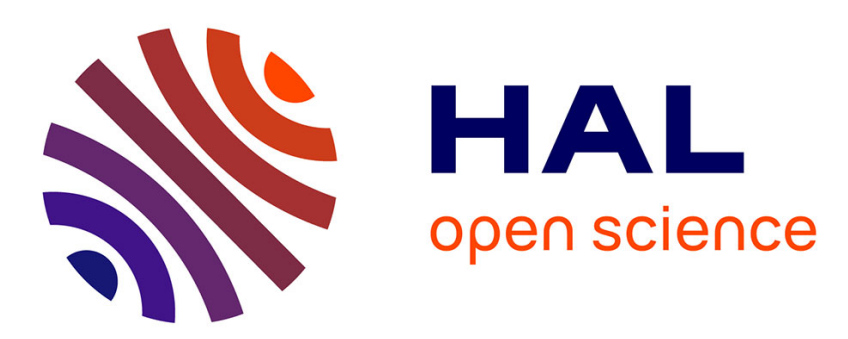

\title{
Signe Rousseau (2012) Food Media: Celebrity Chefs and the Politics of Everyday Interference, Oxford, Berg, 195 p. \\ Joseph Burridge
}

\section{- To cite this version:}

Joseph Burridge. Signe Rousseau (2012) Food Media: Celebrity Chefs and the Politics of Everyday Interference, Oxford, Berg, 195 p.. Review of Agricultural, Food and Environmental Studies, 2016, 97 (1), pp.65-66. 10.1007/s41130-016-0003-8 . hal-03114825

\section{HAL Id: hal-03114825 \\ https://hal.science/hal-03114825}

Submitted on 19 Jan 2021

HAL is a multi-disciplinary open access archive for the deposit and dissemination of scientific research documents, whether they are published or not. The documents may come from teaching and research institutions in France or abroad, or from public or private research centers.
L'archive ouverte pluridisciplinaire HAL, est destinée au dépôt et à la diffusion de documents scientifiques de niveau recherche, publiés ou non, émanant des établissements d'enseignement et de recherche français ou étrangers, des laboratoires publics ou privés. 


\title{
Signe Rousseau (2012) Food Media: Celebrity Chefs and the Politics of Everyday Interference, Oxford, Berg, 195 p.
}

\author{
Joseph Burridge ${ }^{1}$
}

Published online: 29 March 2016

(C) INRA and Springer-Verlag France 2016

Interest in and representation of food has increased substantially over recent years. As a result, it has become increasingly important to comprehend the multiple relationships between food media, our understanding of food, and its consumption. This insightful and stimulating book by Signe Rousseau is an intervention in this area which aims to pursue such an understanding: to capture some of the most significant issues at stake in the way that food undergoes mediation in contemporary societies.

The volume acts as a neat counterpart to Rousseau's (2012) shorter book concerned with some of the ways in which internet-based social media have facilitated a transformation in aspects of our relationships with food and, more directly, the circulation of its representations. In this slightly longer text, which is wider in scope, and more thoroughly grounded in existing cultural sociological literature, Rousseau offers multiple critical analyses of contemporary food media. She discusses, in multiple contexts, the contemporary dynamics of expertise and authority — with a particular focus on the figure of the celebrity chef.

The book covers the intersection of a host of cultural and sociological issues. These include the question of the relationships between culture, democracy, representation, and responsibility. Specifically, Rousseau is keen to explore the relationship between mediation, expertise, and risk, as well as the rather porous boundary existing between knowledge and entertainment and between public and private responsibilities. Clearly, instruction from an 'expert' on food, received through a form of lifestyle entertainment, straddles these boundaries in

Joseph Burridge

joseph.burridge@port.ac.uk

1 University of Portsmouth, Portsmouth, UK rather complicated ways. This observation is at the heart of Rousseau's enterprise.

Rousseau suggests that there is an intense need for both social scientists and citizens to engage in much more critical consumption of food celebrities and journalists and the social and political roles in which they position themselves-as varying blends of experts, commodities/brands, and heroes/ moral entrepreneurs. Fundamentally, the book is concerned with not only exploring relationships between representation and reality in relation to food but also the mediation of responsibility and the associated issues relating to what Rousseau refers to as the politics of 'media interference'- that is, the tension between, on the one hand, our submission to the need for help and expertise, and, on the other hand, our degree of critical thinking for ourselves. Rousseau is concerned that contemporary food media foster relationships with food that are fetishistic, fantastical, illusory, and, in the extent to which they rely upon the watching of others, vicarious. We are therefore both subjected to, and allow ourselves to be subjected to, a relationship with food that is mediated by the expertise of celebrity chefs in a manner that is somewhat disempowering.

Rousseau engages with the politics of obesity-including the contemporary dynamics of stigmatisation and individualisation. In particular, according to Rousseau, media representation of obesity as an important social problem, and social risk, has had the effect of constructing as even more valuable the expertise and authority of celebrity chefs. Associated with this, according to Rousseau, is a recognition and submission to the idea that we (the public) have a need for help and expertise in these matters - that most people now lack the knowledge and ability to feed themselves 'properly'.

Several of the substantive chapters explore a key issue regarding food media by discussing food celebrities who connect with or exemplify something interesting about the issue at stake. So, a chapter about the figure of the professional 
celebrity chef focuses upon Jamie Oliver and considers the version of social activism in which he has increasingly been involved. For Rousseau, the type of Oliver's activism means that he walks a tightrope between 'intervention and interference' (p. 45). By adopting a position as 'moral entrepreneur' and social activist, Oliver encounters the danger that he goes too far and becomes seen as excessively didactic, or judgemental and interfering (also see Hollows and Jones, 2010), thereby undermining any positive contribution his interventions may make. Either way, in this context, the risk for the audience is that they submit to expertise and thereby disavow their sense of responsibility for feeding themselves (and others) - something that means that they are actively involved in disempowering themselves.

In addition to Oliver, Rousseau devotes space to discussing the highly differentiated and historically situated significances of Elizabeth David, Julia Child, M.F.K. Fisher, Nigella Lawson, Anthony Bourdain, Heston Blumenthal, Rachael Ray, and Gillian McKeith. So while Rachel Ray is put forward as a celebrity chef who offers an everywoman/'girl next door' approach to food (as well as offering performed ignorance about it), Gillian McKeith is analysed as a contemporary example of prescriptive authority and advice founded on fundamentally 'bad science'.

Despite Rousseau's overarching concern that we submit all too easily to expertise, she is nevertheless also highly suspicious of the view that we learn meaningfully from the apparent increase in food media content to which we have access. Indeed, she argues that, via a strange kind of logic, the proliferation of information about food actually leads to less learning about it taking place on our part. She suggests therefore that the provision of this advice plays a part in the 'sanctioning of docility' (p. 56). The more information to which we have access, the less we seem to think. In short, Rousseau poses and addresses various questions about how we filter the information to which we have access and expresses concern about how passive we are in this regard.

Although Rousseau makes some use of Ouellete and Hay's (2008) influential application to contemporary reality television of Foucault's work on governmentality, it is arguably somewhat refreshing that the book is not rooted in the work of Bourdieu and Foucault (both of whom are arguably overused/hegemonic points of reference in the contemporary cultural sociology of food). Instead, Rousseau draws predominantly upon authors who have been concerned with the politics of culture and everyday life (for example Adorno and de Certeau).

That the focus is so strongly upon the mediation of food means that the argument is based upon an interrogation of media texts, but not their audiences. Given that the view being advanced is one that views the impact of mediation in an especially critical light, the audience is under-empiricised. That is, the persuasiveness of the argument would be enhanced greatly if there had been detailed engagement with audience responses to the food media in which Rousseau is interested. Certainly, one can imagine a raft of potential $\mathrm{PhD}$ studies and other research projects provoked by a desire to explore empirically many of Rousseau's claims about audience passivity/docility and contemporary levels of knowledge and learning about food (as well as the uses that people make of in their lives of mediated advice about food).

There is much here that will be of interest to those attempting to make sense of the contemporary social significance of food, whether they are university staff or students and whether or not they share Rousseau's specific concerns regarding expertise and interference. Overall, the book should appeal to scholars in the social sciences and humanities and anyone engaged with the interdisciplinary assemblage that is 'food studies', and especially anyone interested specifically in celebrity chefs. For its focus upon the relationship between mediation and everyday life, it should also even prove useful to communications, media, and cultural studies scholars without a direct interest in food.

\section{References}

Hollows J, Jones S (2010) At least he's doing something': moral entrepreneurship and individual responsibility in Jamie's Ministry of Food. Eur J Cult Stud 13(3):307-322

Ouellette L, Hay J (2008) Makeover television, governmentality and the good citizen. Continuum: J Media Cult Stud 22(4):471-484

Rousseau S (2012) Food and social media: you are what you tweet. Altamira Press, Plymouth, $117 \mathrm{p}$ 